\title{
Redesign of Computer-Based Test (CBT) With Total Ergonomic Approach to Reduces an Academic Stress and Improve The CBT Participants Score
}

\author{
Iing ${ }^{1}$, I Putu Gede Adiatmika ${ }^{2}$, Nyoman Adiputra ${ }^{3}$, Ketut Tirtayasa ${ }^{4}$ \\ Physiology Department \\ Medical Faculty, Universitas Islam Al-Azhar \\ Mataram, Indonesia \\ dokter.iing@gmail.com \\ Physiology Department \\ Medical Faculty, Universitas Udayana \\ Denpasar, Bali \\ Physiology Department \\ Medical Faculty, Universitas Udayana \\ Denpasar, Bali
}

\begin{abstract}
Computer-based Test (CBT) is a form of assessment method using a set of Multiple Choice Questions (MCQs). CBT has been applied by many educational institutions to evaluate their student's competencies, one of those institutions is medical school. The standard of the CBT examination in medical school is arranged according to the Indonesia Medical Licensing Examination which listed that the examination must be contained of 200 MCQs in 200 minutes without a break session. This standard causes academic stress on the CBT participants and able to affect the CBT score. Aims: demonstrated the total ergonomic approach CBT redesign in reducing academic stress and improving participant's CBT score compare with the Indonesia Medical Licensing Examination CBT design. Method: this was an experimental study employed a two-period crossover design. The study variable was the academic stress measured by the salivary cortisol level and participant's CBT score. Result: the salivary cortisol level in the middle of CBT was decrease significantly $(\mathrm{p}<0.05)$ as much as $9.88(38.98 \%)$ from the initial salivary cortisol level of $25.34 \mathrm{ng} / \mathrm{mL}$ on the Indonesia Medical Licensing Examination CBT design becoming 15.46 $\mathrm{ng} / \mathrm{mL}$ on the total ergonomic approach CBT redesign. The CBT score also increase significantly as much as 5.23 points $(\mathrm{p}<0.05)$ or increasing $16.20 \%$ from the 32.28 points on the Indonesia Medical Licensing Examination CBT design which become 37.51 points on the total ergonomic approach CBT redesign. Conclusion: the total ergonomic approach CBT redesign was able to reduce $38.98 \%$ of the academic stress and improving $16.20 \%$ participant's CBT score compare with the Indonesia Medical Licensing Examination CBT design.
\end{abstract}

Index Terms - ergonomic, Computer-based Test (CBT), academic stress

\section{INTRODUCTION}

Computer-based Test (CBT) is assessment method conducted by answering a set of Multiple Choice Questions (MCQs) in a computer workstation. CBT is already used by many educational institutions to assess their student's competencies, one of those institutions is medical school. The Indonesian standard of CBT examination in the medical school is arranged based on the Indonesia Licensing Medical Examination standard. The CBT consists of $200 \mathrm{MCQs}$ which has to be done in 200 minutes without a break session.
The data from the Committee of Indonesia Licensing Medical Examination showed that 18,070 medical doctor students took Indonesia Licensing Medical Examination CBT design in 2016. The national passing percentage of Indonesia Licensing Medical Examination, in 2016 was only $56 \%$ with the mean score of 65.89 [1]. The mean score of the CBT Indonesia Licensing Medical Examination in 2017 was only 65.16 , which was not significantly different from the mean score in 2016. The highest score obtained was 100 , while the passing grade score to pass the exam was 66 [2].

In general, the design of the CBT examination consists of some aspects. The first aspects are the working space and 
workstation design which emphasizes the comfort of the room, computer specification, and the Central Processing Unit (CPU). The second aspect is the design of the preparation session. The third aspect is the CBT process. The CBT examination design started when the participant entering until leaving the examination room. During the examination, the participants must be answering 200 MCQs in 200 minutes without a break session. The last design is the determination of the passing grade and the CBT result announcement.

A workshop has conducted to re-assess the design of the Indonesia Medical Licensing Examination CBT design. The design was reviewed and re-organized using a systemic, holistic, inter-disciplinary, active participation, and appropriate technologies employing a total ergonomic approach. A sustainable process through problem identification, priority list determination, working plan, and implementation consolidation was also conducted in this workshop. These steps are expected to be able to reach the main goal of the CBT redesigning [3][4].

This study was not applied to all ergonomic modifications recommended by the workshop. The redesigning of CBT in UNIZAR medical school with the total ergonomic approach consisted of re-setting the workstation computer brightness according to participant brightness preference. This modification can decrease the level of fatigue and improve the focus during the CBT examination.

The redesigning of the CBT in this study were including some aspects, they were (1) modifying the explanation before the CBT session by motivating the participant to take enough rest before the examination, (2) manage an ergonomic posture during the examination, and (3) doing 15 minutes active stretching on the break session. This is required to decrease the musculoskeletal and fatigue complaint after the CBT examination. The CBT redesign could be conducted by adding 15 minutes break session in the form of active stretching. National Institute for Occupational Safety and Health (NIOSH) also recommends that 15 minutes break is required after the 2-hours duration of working with a computer [5].

CBT can cause academic stress for the participant. Anxiety and stress could be appeared due to the pressure of the result. The proper result is required to meet the eligibility to graduate as a general practitioner. The CBT examination also consists of 200 MCQs questions that must be done in 200 minutes without a break session. Shenoy stated that demand is a potential source of stress on the student. The potential source of stress could trigger another academic-related stress. This level of stress is also able to depress the immune system [6].

The better effort is required to improve the CBT score and decrease the stress that might be appeared. This could be done by redesigning the CBT using the total ergonomic approach.

\section{AIMS}

To demonstrate the total ergonomic approach CBT redesign in reducing the academic stress and improving the CBT score in comparison with the standard Indonesia Medical Licensing Examination CBT design.

\section{METHOD}

This study conducted in Computer Based-Test (CBT) Center, Medical School, Universitas Islam Al-Azhar, Mataram. This was an experimental study employed a twoperiod cross-over design. The independent variables were the Indonesia Medical Licensing Examination CBT design and the total ergonomic approach CBT redesign, while the dependent variable was the academic stress measured by the salivary cortisol level after the end of the CBT session on each period. The control variable was the age, weight, height, body mass index (BMI), and the physical environment (temperature, relative humidity, light intensity, and the level of noise).

There were 40 fourth year (seventh semester) medical school students of Universitas Islam Al-Azhar Mataram who participated in this study. The study process was divided into two periods, period I and period II. The participants also divided into two groups, group 1 and group 2, with 20 participants on each group. Group 1 on the period I was participated in the Indonesia Medical Licensing Examination CBT design, while group 2 on the period I participated in total ergonomic CBT redesign. In period II, the cross-over design was applied. Group 1 was participated in total ergonomic CBT redesign, while group 2 on the period I participated in the Indonesia Medical Licensing Examination CBT design.

The Indonesia Medical Licensing Examination CBT design consisted of 200 questions in 200 minutes which started at 09.00 a.m. until 12.20 p.m. without any break session. While the total ergonomic CBT redesign was the Indonesia Medical Licensing Examination CBT design with time modification: at 09.00 a.m. -10.40 a.m. (examination on the first 100 minutes), 10.41 a.m-10.56 a.m. (15 minutes break stretching session), and 10.57 a.m-12.37 a.m. (examination on the second 100 minutes). The total duration for this group was 200 minutes with 15 minutes of break session.

The academic stress was measured by the level of salivary cortisol which taken before the CBT examination and in the middle of the CBT examination (at the minute of 101), while the CBT score was taken after the CBT examination.

The data collected in this study were processed using computer software. The statistical analyses were done using: 1) descriptive test and normality test for each group 2) comparison test between-group after the intervention with the value of $\alpha<0.05$. 


\section{RESULt}

The subject's characteristics measured in this study consisted of their gender, duration of the study, age, height, weight, and body mass index (BMI). The participants were $57.5 \%$ (23 students) female and $42.5 \%$ (17 students) male. All participants were having the same duration of the study

TABLE I

SUBJECT'S CHARACTERISTIC OF CBT

\begin{tabular}{|c|c|c|c|c|c|}
\hline \multirow{2}{*}{ No. } & \multirow{2}{*}{ Variable (s) } & \multirow{2}{*}{ Mean } & \multirow{2}{*}{ SD } & \multicolumn{2}{|c|}{ Range } \\
\hline & & & & Min & Max \\
\hline 1 & Age (year) & 21.12 & 0.56 & 20 & 23 \\
\hline 2 & Height $(\mathrm{cm})$ & 161.55 & 8.98 & 144 & 179 \\
\hline 3 & Weight (kg) & 57.65 & 16.91 & 39 & 110 \\
\hline 4 & BMI $\left(\mathrm{kg} / \mathrm{m}^{2}\right)$ & 21.81 & 4.85 & 16.22 & 38.00 \\
\hline
\end{tabular}

The mean temperature, relative humidity, light intensity, and noise level on both groups were in the same condition during the study. The measurement of these physical environment elements is shown in Table 2, while the

TABLE II

PHYSICAL ENVIRONMENT'S ELEMENT OF CBT LOCATION

\begin{tabular}{|c|c|c|c|c|c|}
\hline \multirow{2}{*}{ No. } & \multirow{2}{*}{ Variable } & \multirow{2}{*}{ Mean } & \multirow{2}{*}{ SD } & \multicolumn{2}{|c|}{ Range } \\
\hline & & & & Min & $\operatorname{Max}$ \\
\hline 1 & Temperature $\left({ }^{0} \mathrm{C}\right)$ & 23.21 & 0.61 & 22.00 & 24.00 \\
\hline 2 & Humidity (\%) & 48.72 & 2.02 & 45.05 & 51.50 \\
\hline 3 & Light Intensity (Lx) & 205.37 & 6.57 & 190.75 & 211.00 \\
\hline 4 & Noise Level (dBA) & 45.07 & 3.43 & 37.33 & 54.67 \\
\hline
\end{tabular}

The effect of the CBT redesigning analyzed by comparing the mean of the salivary cortisol level between the Indonesia Medical Licensing Examination CBT design and total ergonomic approach CBT redesign (after the CBT and already taken six semesters in the medical school. Based on the initial examination conducted in 40 subjects, there was no specific limitation found on the subjects which could affect the study process. The subject characteristic is shown in Table 1.

descriptive and the normality test of the salivary cortisol level is shown in Table 3.

\section{TABLE III}

SALIVARY CORTISOL LEVEL DESCRIPTIVE AND NORMALITY TEST (P)

\begin{tabular}{|c|c|c|c|c|c|c|}
\hline Variable & $\mathrm{N}$ & Mean & SD & Min & $\operatorname{Max}$ & $\mathrm{p}$-value \\
\hline $\begin{array}{l}\text { Salivary Cortisol Level Before Indonesia Medical } \\
\text { Licensing Examination CBT Design }\end{array}$ & 40 & 31.75 & 20.80 & 1.83 & 91.30 & 0.000 \\
\hline $\begin{array}{l}\text { Salivary Cortisol Level in the Middle Indonesia Medical } \\
\text { Licensing Examination CBT Design }\end{array}$ & 40 & 25.35 & 16.77 & 2.06 & 96.22 & 0.000 \\
\hline $\begin{array}{l}\text { Salivary Cortisol Level Before Total Ergonomic } \\
\text { Approach CBT Redesign }\end{array}$ & 40 & 27.98 & 14.22 & 7.07 & 78.81 & 0.000 \\
\hline $\begin{array}{l}\text { Salivary Cortisol Level in the Middle Total Ergonomic } \\
\text { Approach CBT Redesign }\end{array}$ & 40 & 15.46 & 8.46 & 1.16 & 35.74 & 0.078 \\
\hline
\end{tabular}

The Wilcoxon statistical test showed no significant difference in the level of the salivary cortisol $(\mathrm{p}>0.05)$ before the CBT examination on both CBT design. This result indicated that the level of the salivary cortisol was in the same condition before both of the CBT examinations. The mean difference of the salivary cortisol level in the middle of the CBT was significantly different $(p<0.05)$. This result could be indicated that the CBT examination redesigning could affect the salivary cortisol level. The Wilcoxon statistical test also showed that the salivary cortisol level mean difference was statistically different $(p<0.05)$. The mean of the salivary cortisol level in the middle of the total ergonomic approach CBT redesign is lower than the mean of the salivary cortisol level in the middle of the Indonesia Medical Licensing Examination examination). The level of salivary cortisol before the CBT examination was also analyzed to assure the accuracy of the data. The result of the Wilcoxon statistical test is shown in Table 4.

\section{CBT design. \\ The descriptive analysis and the normality test of the} CBT result are shown in Table 5, while the parametric result of the paired sample t-test for the CBT result on both designs is shown in Table 6 .

The paired sample t-test showed that there was a significant difference in the mean of the CBT result between the Indonesia Medical Licensing Examination CBT design and the total ergonomic approach CBT redesign $(\mathrm{p}<0.05)$. The mean score of the CBT result on the total ergonomic approach CBT redesign is higher than the score on the Indonesia Medical Licensing Examination CBT redesign. This result indicated that the total ergonomic approach redesign is effective in improving the CBT score. 
TABLE IV

THE SALIVARY CORTISOL LEVEL BEFORE AND IN THE MIDDLE OF THE CBT

\begin{tabular}{|c|c|c|c|c|c|c|c|}
\hline \multirow[t]{2}{*}{ Variable } & \multirow[t]{2}{*}{$\mathrm{n}$} & \multicolumn{2}{|c|}{$\begin{array}{l}\text { Indonesia Medical } \\
\text { Licensing } \\
\text { Examination CBT } \\
\text { Design }\end{array}$} & \multicolumn{2}{|c|}{$\begin{array}{l}\text { Total Ergonomic } \\
\text { Approach CBT } \\
\text { Redesign }\end{array}$} & \multirow[t]{2}{*}{ Mean } & \multirow[t]{2}{*}{ p-value } \\
\hline & & Mean & SD & Mean & SD & & \\
\hline The salivary cortisol level before CBT & 40 & 31.75 & 20.80 & 27.98 & 14.22 & 3.77 & 0,502 \\
\hline $\begin{array}{l}\text { The salivary cortisol level in the middle of } \\
\text { CBT }\end{array}$ & 40 & 25.34 & 16.77 & 15.46 & 8.46 & 9.88 & 0.000 \\
\hline The difference of the salivary cortisol level & 40 & 6.41 & 13.32 & 12.51 & 13.34 & 6.10 & 0.023 \\
\hline
\end{tabular}

\section{DISCUSSION}

The statistical analysis on the mean of the salivary cortisol level before the CBT examination was not significantly different on both of the CBT design ( $p>0.05)$. The mean salivary cortisol level before the CBT with Indonesia Licensing Medical Examination design was $31.75 \mathrm{ng} / \mathrm{mL}$, while the mean salivary cortisol level before the CBT with the total ergonomic approach redesign was $27.98 \mathrm{ng} / \mathrm{mL}$.

The salivary cortisol level was decreased significantly in the total ergonomic CBT design in comparison with the Indonesia Medical Licensing Examination CBT design as much as $6.10(\mathrm{p}<0.05)$. The level of the salivary cortisol in the middle of the CBT examination also decrease significantly $(\mathrm{p}<0.05)$ as much as 9.88 or $38.98 \%$ from $25.34 \mathrm{ng} / \mathrm{mL}$ on the Indonesia Medical Licensing Examination CBT design becoming $15.46 \mathrm{ng} / \mathrm{mL}$ on the total ergonomic approach CBT redesign. The normal range of the salivary cortisol using Cortisol Saliva Elisa Version: 6.0 from Diagnostic Biochem Canada Inc. Standard is 5$1.6 \mathrm{ng} / \mathrm{mL}$ [7]. This result is indicated that the redesigning of the CBT effective in reducing the stress level on the CBT participant.

TABLE V

CBT RESULT DESCRIPTIVE DATA AND NORMALITY TEST

\begin{tabular}{lcccccc}
\hline Variable & $\mathrm{n}$ & Mean & SD & Min & Max & \\
\hline $\begin{array}{l}\text { Indonesia } \\
\text { Medical }\end{array}$ & & & & & & \\
$\begin{array}{l}\text { Licensing } \\
\text { Examination }\end{array}$ & 40 & 32.28 & 5.58 & 17.00 & 44.00 & 0.394 \\
$\begin{array}{l}\text { CBT Design } \\
\text { Total Ergonomic } \\
\text { CBT Redesign }\end{array}$ & 40 & 37.51 & 5.23 & 26.00 & 48.00 & 0.315 \\
\hline
\end{tabular}

Stress is a condition that appeared because of the stressor and able to affect the level of cortisol hormone in the body. Stress also could be defined as a homeostasis disturbance which affected the physiological balance because of the stimulation on the physical and psychological aspect.

Adiputra (2002) stated that workload is a factor of stressor that can be classified into two major groups: external and internal load. The external load could be defined as a workload that originates from outside the human body, such as environmental factors, job complexity, workplace, and working duration. While the internal load (strain) defined as a workload that originates from inside the human body. This workload is closely related with the expectation, wish, satisfaction, etc [8].

Cortisol is the main glucocorticoid secretes by the adrenal cortex [9]. Cortisol also is known as the final effector point on hypothalamus-hypophysis-adrenal (HPA) [10]. The cortisol hormone secretion is affected by the three mechanisms. Hypothalamus produces CorticotrophinReleasing Hormone (CRH) which would stimulate the release of an Adreno-Corticotropic Releasing Hormone $(\mathrm{ACTH})$ from the anterior hypophysis. ACTH would stimulate the release of the cortisol from the adrenal cortex (fasciculate and reticular zone). These regulations manage by the diurnal system. The ACTH peak level happens at 08.00-09.00 a.m or during the daily activities in the morning and the lowest level is happened at the night or during recess time) and stress [9].

The level of hormones serum (CRH, cortisol, and epinephrine) are changes as the adaptive response to the stress. These changes are required to control a fight or flight response to the stress [11]. Cortisol plays an important role in adaptation to stress. All type of stress is the main factor which stimulates the release of the cortisol. Stress would stimulate the activation of the CRH-ACTH-Cortisol system on the central nervous system. The total of the increasing amount of cortisol is equal to the stress stimulation intensity. The higher the level of stress, the higher the amount of cortisol would release in the body [9].

The increase level of cortisol secretion also affects some metabolic processes in the body. The increase level of cortisol able to improve the mobilization of fats and protein, reduce the sensitivity of insulin, reduce the release of the growth hormones (GH-T3) and reduce the inflammation responses [12].

Body also responses to the stress by increasing the work of the heart, respiration rate, increasing the blood flow and increasing the supply of energy to the muscles and brain [13]. This process made the body easily get exhausted.

Academic stress causes academic pressure which able to induce anxiety. Anxiety could affect the focus and concentration during the examination. Concentration could be defined as an effort to focus on an object, such as mind concentration, attentiveness, etc [14]. Good concentration would maximize the effort on answering the questions during the CBT examination.

There are some specific methods use to prevent workinduced-stress, one of them is redesigning the working 
tasks or redesigning the workplace, and using a more ergonomic working time [15]. Internal and external factor also contributes a major role in decreasing the cortisol hormones in this study. The internal factor was the redesigning of the $\mathrm{CBT}$ session. Before the $\mathrm{CBT}$ session, a formal explanation about CBT rules was modified by motivating the ergonomic postures during the CBT session. Another internal factor is consisted of maintaining comfort, healthy, and safe by modifying the duration of the CBT session, from 200 minutes without any break session to 215 minutes with 15 minutes active stretching in the break session. These processes and setting able to decrease the CBT participant's stress.

Bartsch and Evelyn (2005) define stress as tension. Tension could be released by doing a stretching exercise [16]. The stretching is effective to decrease fatigue and anxiety during the CBT session [17].

TABLE VI

THE EFFECT OF CBT DESIGN ON CBT RESULT

\begin{tabular}{lccccc}
\hline Variable & $\mathrm{n}$ & Mean & $\mathrm{SD}$ & $\begin{array}{c}\text { Mean } \\
\text { Difference }\end{array}$ & $\begin{array}{c}\mathrm{p} \\
\text { value }\end{array}$ \\
\hline $\begin{array}{l}\text { Indonesia } \\
\text { Medical }\end{array}$ & & & & & \\
$\begin{array}{l}\text { Licensing } \\
\text { Examination CBT }\end{array}$ & 40 & 32.28 & 5.58 & & \\
$\begin{array}{l}\text { Design Result } \\
\text { Total Ergonomic }\end{array}$ & & & & 5.23 & 0.000 \\
\begin{tabular}{l} 
CBT Redesign \\
\hline
\end{tabular} & 40 & 37.51 & 5.23 & & \\
\hline
\end{tabular}

The mean CBT score result was significantly different on the both CBT design $(\mathrm{p}<0.05)$, with the mean score of 32.28 on the Indonesia Medical Licensing Examination CBT design and 37.51 on the total ergonomic approach CBT redesign. There were 5.23 points $(16.20 \%)$ difference between both designs. The mean CBT result was higher on the total ergonomic approach CBT redesign than the CBT score on the Indonesia Medical Licensing Examination CBT design. This statistical result showed that total ergonomic approach CBT redesign is effective to improve the CBT result.

The total ergonomic approach CBT redesign involving a process of setting a healthy, safe, and comfortable environment for the CBT examination. The main goal of this redesign process is to improve the result of the CBT examination [3][4].

The effect of the CBT redesigning was shown by the decrease of the salivary cortisol level and the improvement of the CBT score. The total ergonomic approach CBT redesign is confirmed statistically able to improve the CBT score and decrease a $38.98 \%$ salivary cortisol level.

\section{CONCLUSION}

The total ergonomic approach CBT redesign was able to decrease $38.98 \%$ of the academic stress and improve $16.20 \%$ of the CBT score in comparison with the Indonesia Medical Licensing Examination CBT design.

\section{REFERENCES}

[1] PNUKMPPD, "Committee of Indonesia Licensing Medical Examination. Laporan Hasil Uji Kompetensi Mahasiswa Program Profesi Dokter periode Februari, Mei, Agustus, November 2016". Jakarta: Ristekdikti. 2016.

[2] PNUKMPPD, "Committee of Indonesia Licensing Medical Examination. Laporan Hasil Uji Kompetensi Mahasiswa Program Profesi Dokter periode Februari, Mei, Agustus, November 2017”. Jakarta: Ristekdikti. 2017.

[3] Manuaba, I.B.A, "Ergonomi Meningkatkan Kinerja Tenaga Kerja dan Perusahaan. Dalam Hermansyah editor. Prosiding Simposium dan Pameran Ergonomi Indonesia 2000”. Bandung : ITB Press. p. 11-9. 2000

[4] Manuaba, I.B.A, a. "Organisasi Kerja, Ergonomi dan Produktivitas. Seminar Nasional Ergonomi”, Jakarta, 9 - 10 April. 2003.

[5] NIOSH. "Observation-Based Posture Assessment: Review of Current Practice and Recommendations for Improvement", National Institute for Occupational Safety and Health, Cincinnati. 2014.

[6] Shenoy, U.A. "Colledge-stress and symptom-expression in international

"students:a_comperative_study.Diunduh_dari:http://scholarlib.vt.edu /thesis/available/etd.07022001-115853 tanggal 31 Juli 2004. 2004.

[7] DBC. "Cortisol Saliva Elisa Version 6.0 Effective": September 13,2018. Canada: Diagnostics Biochem Canada Inc. 2018.

[8] Adiputra, I.N. "Denyut Nadi dan Kegunaannya Dalam Ergonomi. Jurnal Ergonomi Indonesia". Vol. 3. No. 16: 22-26. 2002.

[9] Sherwood, L. "Fisiologi Manusia Dari Sel ke Sistem". (B. U. Pendit, H. O. Ong, A. A. Mahode, \& D. Ramadhani, Eds.) (Edisi 8). Jakarta: EGC. 2014.

[10] Li, X., Xiang, X., Hu, J., Goswami, R., Zhang, A., Wang, Y., Yang, S. "Association Between Serum Cortisol and Chronic Kidney Disease in Patients with Essential Hypertension". Kidney \& Blood, 41(1), 384-391. 2016.

[11] Ranabir, S., \& Reetu, K. "Stress and hormones. Indian Journal of Endocrinology and Metabolism, 15(1), 18-22. 2011.

[12] Guilliams, T. \& Edwards, L. "Chronic Stres and The HPA Axis". The Standard Poin Institute, 9 (2) :1-12. 2010.

[13] Carrasco, G.A. \& Van de Kar. "Neuroendocrine Pharmacology of Stress". European Journal of Pharmacology, 463: 235-272. 2003.

[14] Djamarah, Syaiful Bahri. "Psikologi Belajar. Jakarta: Rineka Cipta2008.

[15] Tarwaka, Sholichul, Lilik Sudiajeng, "Ergonomi Untuk Keselamatan, Kesehatan Kerja dan Produktivitas". Surakarta : Uniba Press. 2004.

[16] Bartsch, K., \& Evelyn "The wounded healer (Terjemahan)". Panji Graha, Semarang. 2005.

[17] Anderson, B. "Stretching in The Office". (Ratih Ramelan, Pentj). Jakarta: PT. Serambi Ilmu Semesta2010. 